\title{
Cytoprotective effect of methanolic extract of Nardostachys jatamansi against hydrogen peroxide induced oxidative damage in $\mathrm{C} 6$ glioma cells
}

\author{
Kshitija Dhuna ${ }^{1}$ Vikram Dhuna ${ }^{\circledR}$, Gaurav Bhatia², Jatinder Singh \\ and Sukhdev Singh Kamboj1,
}

1Department of Molecular Biology and Biochemistry, Guru Nanak Dev University, Amritsar- Punjab, India; ${ }^{2}$ Department of Biotechnology, DAV College, Amritsar, Punjab, India

Oxidative stress has been implicated as an important factor in the process of neurodegeneration and hydrogen peroxide $\left(\mathrm{H}_{2} \mathrm{O}_{2}\right)$ is one of the most important precursors of reactive oxygen species (ROS), responsible for many neurodegenerative diseases. This study used extracts from Nardostachys jatamansi rhizomes, known for nerve relaxing properties in Ayurvedic medicine, to ascertain their protective role in $\mathrm{H}_{2} \mathrm{O}_{2}$-induced oxidative stress in $\mathrm{C} 6$ glioma cells. The protective effect of methanolic, ethanolic and water extracts of $N$. jatamansi (NJ-MEx, NJ-EEx and NJ-WEx respectively) was determined by MTT assay. NJ-MEx significantly protected against $\mathrm{H}_{2} \mathrm{O}_{2}$ cytotoxicity when cells were pretreated for $24 \mathrm{~h}$. The level of antioxidant enzymes, catalase, superoxide dismutase (Cu-ZnSOD), glutathione peroxidase (GPx), and a direct scavenger of free radicals, glutathione (GSH), significantly increased following pre-treatment with NJ-MEx. Lipid peroxidation (LPx) significantly decreased in NJ-MEx-pretreated cultures. The expression of a C6 differentiation marker, GFAP (glial fibrillary acidic protein), stress markers HSP70 (heat shock protein) and mortalin (also called glucose regulated protein 75 , Grp75) significantly decreased when cells were pre-treated with NJ-MEx before being subjected to $\mathrm{H}_{2} \mathrm{O}_{2}$ treatment as shown by immunofluorescence, western blotting and RT-PCR results. The present study suggests that NJ-MEx could serve as a potential treatment and/or preventive measure against neurodegenerative diseases.

Key words: antioxidant enzymes, C6 glioma, hydrogen peroxide, Nardostachys jatamansi.

Received: 10 May, 2012; revised: 12 November, 2012; accepted: 21 February, 2013; available on-line: 20 March, 2013

\section{INTRODUCTION}

A large class of common diseases involving progressive loss of cognitive functions have been grouped as neurodegenerative disorders. No conclusive hypothesis has been proposed to date to explain the chemical and pathological events in a diseased neuronal cell but it is accepted that all neurodegenerative disorders, which include Alzheimer's disease (AD), Huntington's disease (HD), Parkinson's disease (PD) and cerebral ischemia (Chatterjee et al., 2000; Liu et al., 2002; Murphy, 1999; Simonian \& Coyle, 1996) are upshots of oxidative stress and apoptosis. Brain cells are particularly vulnerable to oxidative damage due to their high energy expenditure and oxygen demand. Glial cells of the brain were ear- lier thought to provide little passive architectural and trophic support to neurons, but it is now clear that they actively participate in bidirectional communication (Hertz et al., 1999). The CNS response to trauma, viral infection, inflammation, excitotoxicity, hypoxia/ischemia and degenerative diseases manifests reactive gliosis (Eng \& Ghirnikar, 1994). Since C6 glioma, an N-nitrosomethylurea-induced rat glial cell line, shows normal glial cell properties, it has been extensively used as an in vitro glial model system (Benda et al., 1968; Singh \& Kaur, 2009). Upregulation of glial fibrillary acidic protein (GFAP) is a marker for reactive gliosis, trauma and degeneration in CNS, whereas HSP70 and mortalin (Heat shock protein 75/Hsp75/mtHsp70/Grp75/TRAP-1) are useful stress response markers. Experiments using both animal models and tissue culture systems have indicated the overexpression of HSP70 in neurons and glial cells under stress (Giffard et al., 2004; Rajdev \& Sharp, 2000). Mortalin is a mitochondrial member of the heat shock protein 70 (HSP70) family and is an essential mitochondrial chaperone. Mortalin is not heat-inducible, but like other HSP70 members, has been shown to be upregulated by various cellular insults including glucose deprivation, oxidative stress, thyroid hormone treatment, and ultraviolet A radiation (Carette et al., 2002; Hadari et al., 1997; Mitsumoto et al., 2002). Mortalin induction was also found in focal cerebral ischemia (Massa et al., 1995). Increased mortalin levels have been shown to be associated with cellular stress in smooth muscle and focal ischemia (Taurin et al., 2002).

e-mail: drsukhdev2002@gmail.com (Sukhdev Singh); vikramdhuna@gmail.com (Vikram Dhuna)

Abbreviations: AD, Alzheimer's disease; ANOVA, analysis of variance; CNS, central nervous system; Cu-ZnSOD, copper-zinc superoxide dismutase; DDW, double distilled water; DEPC, diethylpyrocarbonate; DMEM, Dulbecco's modified eagle's medium; dNTP, deoxyribonucleoside triphosphate; Taq, Thermus aquaticus; EDTA, ethylenediamine tetraacetic acid; DTT, dithiothreitol; GFAP, glial fibrillary acidic protein; GPx, glutathione peroxidase; Grp75, glucose-regulated protein 75; GSH, reduced glutathione; HD, Huntington's disease; HRP, horse raddish peroxidise; MTT, 3-[4,5-dimethylthiazol-2-yl]- 2,5-diphenyl tetrazolium bromide; HSP70, heat shock protein $70 \mathrm{kDa}$; IC50, inhibitory concentration producing $50 \%$ cell death, IgG, Immunoglobulin G; MDA, malondialdehyde; NADPH, nicotinamide adenine dinucleotide phosphate reduced; NBT, nitroblue tetrazolium; NGS, normal goat serum; PMSF, phenylmethylsulfonyl fluoride; NJ-EEx, N. jatamansi ethanolic extract; NJ-MEx, N. jatamansi methanolic extract; NJ-WEx, N. jatamansi water extract; PAGE, polyacrylamide gel eletrophoresis; PBS, phosphate buffered saline; PBST, phosphate buffered saline with tween 20; PCR, polymerase chain reaction; PD, Parkinson's disease; PVDF, polyvinylidene difluoride; ROD, Relative optical density; SDS, sodium dodecyl sulphate; TBA, thiobarbituric acid; TBS, Tris-buffered saline; TBST, Tris-buffered saline and Tween 20. 
Brain has several antioxidant defence mechanisms to control mitochondrial decay-inducing oxidative stress molecules. The cytosol of brain cells has catalase which hydrolyzes $\mathrm{H}_{2} \mathrm{O}_{2}$ (Borniquel et al., 2006) and glutathione peroxidases $(\mathrm{GPx})$ which reduce organic hydroperoxides (Bjornstedt et al., 1994). Mitochondria of neurons of the human CNS have superoxide dismutase which converts $\cdot \mathrm{O}_{2}^{-}$to $\mathrm{H}_{2} \mathrm{O}_{2}$ and prevents ${ }^{\circ} \mathrm{ONOO}^{-}$formation from $\cdot \mathrm{O}_{2}-$ and $\cdot \mathrm{NO}$ (Bayir et al., 2007). Exogenous $\mathrm{H}_{2} \mathrm{O}_{2}$ can elevate oxidative stress beyond the protective capacity of endogenous antioxidant defences and induces apoptotic cell death by initiating mitochondrial dysfunction (Maroto and Perez-Polo, 1997).

So far, no effective drugs are available to successfully prevent neuronal cell death in neurodegenerative diseases, however, Ayurveda has numerous plants with amazing properties. Some of the actions of herbs that are described in Ayurveda are quite new to the conventional medicine. Polyphenolic compounds, found in vegetables, fruits, dry fruits, plant extracts, wine, and tea, are natural antioxidants having useful prophylactic properties for the treatment of excitotoxic and oxidative cell death (Zhang et al., 2010). One such plant, Nardostachys jatamansi D.C. (Valerianaceae) is an Indian herb used in the Ayurvedic system of medicine for centuries to treat mental ailments. N. jatamansi was mentioned by Susruta in Sushruta samhita, an ancient book written centuries ago, as nerve tonic. Earlier studies on N. jatamansi rhizomes showed high phenolic content and antioxidant properties (Rasheed et al., 2010; Sharma \& Singh, 2012). However, no study has been published yet at the cellular level, using markers of cellular stress and antioxidant enzymes against $\mathrm{H}_{2} \mathrm{O}_{2}$-induced oxidative stress. The present study investigated the protective and antioxidant effect of $N$. jatamansi-methanolic extract (NJ-MEx), N. jatamansi-ethanolic extract (NJ-EEx) and $N$. jatamansi-water extract (NJ-WEx) against $\mathrm{H}_{2} \mathrm{O}_{2}$-induced oxidative stress in C6 glioma cells using antioxidant enzymes, GSH content, lipid peroxidation, GFAP, HSP70 and mortalin as markers.

\section{MATERIALS AND METHODS}

Chemicals and reagents. The primary antibodies used for the Western blot and/or immunocytofluorescent analysis were monoclonal rabbit anti-GFAP (SigmaAldrich), mouse anti-HSP70 (Clone BRM-22, Sigma-Aldrich), mouse anti-Grp75 (mortalin) (Abcam), and mouse anti- $\alpha$-tubulin (Clone AA13, Sigma-Aldrich). The secondary antibodies used were goat anti-mouse IgG:HRP (Sigma), anti-rabbit IgG:HRP (Bangalore genei), anti-mouse Alexa Fluor 568 (Invitrogen) and anti-rabbit Alexa Fluor 488 (Invitrogen). 3-[4,5-dimethylthiazol-2-yl]-2,5-diphenyl tetrazolium bromide (MT'T) was from Sigma-Aldrich. The PCR reagents which include dNTP Mix, Random Hexamer Primer, 100bp ladder, Reverse Transcriptase and Taq DNA Polymerase were from Fermentas Life Sciences. Primers for synthesis of cDNA for GFAP, $\alpha$-tubulin, HSP70 and mortalin were from Biolink, India. All other chemicals and reagents including FC reagent, hydrogen peroxide, EDTA, L-ascorbic acid, sodium hydroxide and solvents were procured in their purest form available commercially from Qualigens, Himedia and Sisco Research Laboratories (Indian companies).

Preparation of NJ-MEx, NJ-EEx and NJ-WEx. Rhizomes of $N$. jatamansi were procured from local Ayurvedic merchants and identified at the Department of Botanical and Environmental Sciences, Guru Nanak Dev
University, Amritsar, India. The rhizomes were powdered and $10 \mathrm{~g}$ of dry rhizome powder was suspended in $100 \mathrm{ml}$ of methanol or ethanol or distilled water and kept stirring for 48 hours at $30 \pm 5^{\circ} \mathrm{C}$ followed by filtration with muslin cloth and centrifugation at $17000 \times g$ for $15 \mathrm{~min}$. The supernatant thus obtained was concentrated with a vacuum rotatory evaporator (Buchi, Switzerland) under reduced pressure and air dried to make powder. These were further diluted in respective solvent to make final concentration of $200 \mu \mathrm{g} / \mathrm{ml}$ each for NJMEx, NJ-EEx and NJ-WEx.

Cell culture and treatments. Rat C6 glioma cell line was obtained from the National Centre for Cell Sciences, Pune, India and maintained on Dulbecco's Modified Eagle's Medium (DMEM) supplemented with streptomycin $(100 \mathrm{U} / \mathrm{ml})$, gentamycin $(100 \mu \mathrm{g} / \mathrm{ml}), 10 \%$ FCS (Life Technologies) at $37^{\circ} \mathrm{C}$ and humid environment containing $5 \% \mathrm{CO}_{2}$. The $\mathrm{H}_{2} \mathrm{O}_{2}$ dose (IC50) for cytoprotective studies was calculated by treating cells with $\mathrm{H}_{2} \mathrm{O}_{2}(7.8 \mu \mathrm{M}$ to $1000 \mu \mathrm{M}$ diluted in medium) at 50\% confluency for 24 $\mathrm{h}$ in serum-free medium. The C6 glioma cells were treated with NJ-MEx, NJ-EEx or NJ-WEx at concentration from $1.5 \mu \mathrm{g} / \mathrm{ml}$ to $50 \mu \mathrm{g} / \mathrm{ml}$ diluted in medium for $24 \mathrm{~h}$ at $30-40 \%$ confluency and then subjected to $\mathrm{H}_{2} \mathrm{O}_{2}$ (IC50 concentration) treatment for $24 \mathrm{~h}$ in serum-free medium. The medium of control culture without $\mathrm{H}_{2} \mathrm{O}_{2}$ and without extract was replaced with a fresh one. For enzyme assays, immunofluorescence, western blotting and RT-PCR the following four groups were used: untreated cultures, control; NJ-MEx-treated cultures, NJ-MEx; NJ-MEx-pretreated cultures before $\mathrm{H}_{2} \mathrm{O}_{2}$ treatment, $\mathrm{NJ}-\mathrm{MEx}+\mathrm{H}_{2} \mathrm{O}_{2}$; and $\mathrm{H}_{2} \mathrm{O}_{2}$-treated cultures, $\mathrm{H}_{2} \mathrm{O}_{2}$.

Cell viability assay. MTT was used to assess cell integrity and cytotoxicity by monitoring the uptake of the vital mitochondrial dye 3-[4,5-dimethylthiazol-2-yl]2,5-diphenyl tetrazolium bromide (MTT) by cell mitochondria (Hansen et al., 1989).

Chemical standardization of NJ-MEX and nature of active components. NJ-MEx was subjected to preliminary phytochemical screening for alkaloids, amino acids, anthraquinone, flavonoids, phytosterols, saponins, steroids, tannins, triterpenoids and reducing sugars following the methods of (Harborne, 1998)). It was further subjected to thin-layer chromatography (TLC) using chloroform: methanol (24:1) as solvent. TLC plate was subjected to iodine vapours for observation.

\section{Estimation of activities of antioxidant enzymes and levels of antioxidants}

Preparation of whole cell extract. Cells were washed twice with ice-cold PBS ( $\mathrm{pH} 7.4)$, harvested with PBS-EDTA $(1 \mathrm{mM})$, and centrifuged at $400 \times \mathrm{g}$ for 10 min. The pellet so obtained was homogenized in 10 volumes of chilled homogenizing buffer containing $250 \mathrm{mM}$ Sucrose, $12 \mathrm{mM}$ Tris- $\mathrm{HCl}, 0.1 \mathrm{mM}$ DT'T, at pH 7.4 by repeated vortex mixing at $4^{\circ} \mathrm{C}$ for $10-15$ minutes. Homogenates were centrifuged at $12000 \times \mathrm{g}$ for $10 \mathrm{~min}$ at $4^{\circ} \mathrm{C}$. The supernatant was transferred to chilled eppendorf tubes and used for the following estimations.

Estimation of catalase and CuZnSOD. Catalase activity was measured according to the method of (Aebi, 1984). The rate of decomposition of $\mathrm{H}_{2} \mathrm{O}_{2}$ by catalase was measured spectrophotometrically at $240 \mathrm{~nm}$. The reaction mixture $(1 \mathrm{ml})$ contained $0.8 \mathrm{ml}$ phosphate buffer $(0.2 \mathrm{M}, \mathrm{pH} 7.0)$ containing $12 \mathrm{mM} \mathrm{H}_{2} \mathrm{O}_{2}$ as substrate, $100 \mu \mathrm{l}$ enzyme sample and distilled water to make up the volume. The decrease in absorbance/minute at $240 \mathrm{~nm}$ was recorded against $\mathrm{H}_{2} \mathrm{O}_{2}$-phosphate buffer as blank. 
Superoxide dismutase was estimated according to the method of Kono (1978). This method is based on the principle of the inhibitory effects of SOD on the reduction of nitroblue tetrazolium (NBT) dye by superoxide radicals, which are generated by the autoxidation of hydroxylamine hydrochloride. The reduction of NBT was followed by an absorbance increase at $540 \mathrm{~nm}$. In the test cuvette, the reaction mixture contained the following: $1.3 \mathrm{ml}$ sodium carbonate buffer $(50 \mathrm{mM}, \mathrm{pH} 10), 500 \mu \mathrm{l}$ NBT $(96 \mu \mathrm{M})$ and $100 \mu \mathrm{l}$ triton $\mathrm{X}-100(0.6 \%)$. The reaction was initiated by addition of $100 \mu \mathrm{l}$ of hydroxylamine hydrochloride $(20 \mathrm{mM}), \mathrm{pH}$ 6.0. After $2 \mathrm{~min}, 50 \mu \mathrm{l}$ enzyme sample was added and the percentage inhibition in the rate of NBT reduction was recorded.

Reduced glutathione (GSH) and glutathione peroxidase (GPx). Total glutathione was measured as described by Sedlak \& Lindsay (1968). For GSH content, $100 \mu \mathrm{l}$ cell homogenate was mixed with $4.4 \mathrm{ml}$ of $10 \mathrm{mM}$ EDTA and $500 \mu \mathrm{l}$ of trichloroacetic acid $50 \%$ $\mathrm{w} / \mathrm{v})$. Contents were centrifuged at $3000 \times \mathrm{g}$ for $15 \mathrm{~min}$ at $4^{\circ} \mathrm{C}$. The supernatant so obtained was mixed with $50 \mu \mathrm{l}$ of 5,5'-dithiobis(2-nitrobenzoic acid) $(10 \mathrm{mM})$ and absorbance was measured at $540 \mathrm{~nm}$. Standard curve was prepared using pure glutathione.

Glutathione peroxidase activity was measured indirectly by monitoring the oxidation of NADPH. The reaction mixture $(1 \mathrm{ml})$ containing $100 \mathrm{nM}$ GSH, 15

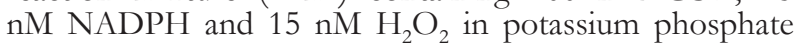
buffer $(50 \mathrm{mM}, \mathrm{pH} 7.5)$ was mixed with sample $(50 \mu \mathrm{l})$ and the change in absorbance was monitored at $340 \mathrm{~nm}$. One unit of glutathione peroxidase activity is defined as $1 \mu \mathrm{mol}$ of NADPH oxidized per min at $\mathrm{pH} 7.5$ at $25^{\circ} \mathrm{C}$.

Lipid peroxidation (LPx). The method of Buege \& Aust (1978) was followed to measure the lipid peroxidation level. Lipid peroxides are unstable and decompose to form a complex series of compounds including reactive carbonyl compounds. Polyunsaturated fatty acid peroxides generate malondialdehyde (MDA) upon decomposition. MDA forms a 1:2 adduct with thiobarbituric acid (TBA) that gives a red product having absorption maximum at $532 \mathrm{~nm}$. A $100 \mu \mathrm{l}$ sample was incubated with $100 \mu \mathrm{l}$ each of $\mathrm{FeSO}_{4}(1 \mathrm{mM})$, ascorbic acid $(1.5$ $\mathrm{mM})$ and Tris/ $\mathrm{HCl}$ buffer $(150 \mathrm{mM}, \mathrm{pH} 7.1)$ in a final volume of $1 \mathrm{ml}$, made up with DDW, for 15 minutes at $37^{\circ} \mathrm{C}$. The reaction was stopped by adding $1 \mathrm{ml}$ of trichloroacetic acid $(10 \% \mathrm{w} / \mathrm{v})$. This was followed by addition of $2 \mathrm{ml}$ thiobarbituric acid $(0.375 \% \mathrm{w} / \mathrm{v})$. After keeping in boiling water-bath for $15 \mathrm{~min}$, contents were cooled and then centrifuged at $3000 \times \mathrm{g}$ for $10 \mathrm{~min}$ at $4^{\circ} \mathrm{C}$. The absorbance of supernatant so obtained was measured at $532 \mathrm{~nm}$.

Immunocytochemistry. All cells, control and treated, were rinsed three times with ice-cold $0.1 \mathrm{M}$ PBS and fixed with paraformaldehyde (4\%) for 30 minutes. Permeabilization was carried out with $0.32 \%$ PBST for 15 minutes. Coverslips were washed thrice with $0.1 \%$ PBST followed by blocking with 5\% NGS (Normal Goat Serum) prepared in $0.1 \%$ PBST for $1 \mathrm{~h}$ at room temperature. Cells were incubated with rabbit anti-GFAP (1:500), mouse anti-HSP70 (1:500) and mouse anti-mortalin $(1: 100)$, diluted in $0.1 \% \mathrm{PBST}$, for $24 \mathrm{~h}$ at $4^{\circ} \mathrm{C}$ in humid chamber. Coverslips were then washed with $0.1 \%$ PBST thrice. Secondary antibody anti-rabbit Alexa Fluor 488 and anti-mouse Alexa Fluor 568 was applied diluted (1:200) in $0.1 \%$ PBST for $2 \mathrm{~h}$ at room temperature. Coverslips were washed three times with $0.1 \%$ PBST and final washing was given with $0.1 \mathrm{M}$ PBS. These coverslips were then mounted on slides with anti-fading mounting media, Fluoromount (Sigma), and were observed under a
Nikon E600 fluorescence microscope. Images were captured using a Cool Snap CCD camera and the pictures were analyzed using ImageJ $1.44 \mathrm{p}$, NIH, USA.

Protein assay and Western blotting. All cells, treated and untreated, were rinsed twice with ice-cold PBS and harvested with PBS-EDTA. The cells from $25 \mathrm{~cm}^{2}$ culture flasks of same group were pooled together and centrifuged at $400 \times g$ for $5 \mathrm{~min}$ at $4^{\circ} \mathrm{C}$. Cell pellet was homogenized in 5 volumes of chilled homogenizing buffer (50 mM Tris, $150 \mathrm{mM} \mathrm{NaCl}, 1 \mathrm{mM}$ EDTA, 100 $\mu \mathrm{M} \mathrm{NaVO}, 1 \mathrm{mM}$ PMSF and $0.5 \mathrm{mM}$ DTT) and centrifuged for $10 \mathrm{~min}$ at $12000 \times g$ at $4^{\circ} \mathrm{C}$. Protein content in the supernatant was determined by the Bradford method. Each homogenate was then diluted in homogenizing buffer to equal protein content in all the samples. The samples were mixed 1:1 with sample buffer $(0.25 \mathrm{M}$ Tris/HCl, pH 6.8, 20\% glycerol, 4\% SDS (sodium dodecyl sulfate), $10 \% \beta$-mercaptoethanol and $1 \mathrm{mg}$ bromophenol blue] and stored at $-20^{\circ} \mathrm{C}$. Samples containing 30 $\mu \mathrm{g}$ of protein were electrophoresed on one-dimensional 11\% SDS/PAGE under standard denaturing conditions. The separated proteins were then blot transferred onto a PVDF membrane using a western blotting system at 25 $\mathrm{V}$ for 3 hours. Subsequently, membranes were blocked for $24 \mathrm{~h}$ at room temperature with 5\% skimmed milk solution in TBST buffer $(13.3 \mathrm{mM}$ Tris. $0.8 \%, \mathrm{w} / \mathrm{v}, \mathrm{NaCl}$; $\mathrm{pH}$ 7.6) containing $0.1 \%$ Tween-20 (Sigma) and immediately incubated with rabbit anti-GFAP (1:3000), mouse anti-HSP70 (1:1000), mouse anti-mortalin (1:3000) and mouse anti-tubulin $(1: 3000)$ monoclonal antibodies overnight. After three washes for 10 minutes each in TBST, horse radish peroxidase-conjugated anti-mouse $\operatorname{IgG}$ $(1: 3000)$ and anti-rabbit IgG (1:3000) secondary antibodies were added for $2 \mathrm{~h}$ for hybridization with primary antibodies followed by three washes in TBST for 10 minutes and finally washed with TBS. Immunoreactive bands were visualized using the EZ-ECL Chemiluminescence Kit for HRP detection (Biological Industries, Israel) according to the manufacturer's instructions and exposed to Super RX Fuji X-ray film. The films were then developed and the antibody-labeling intensity (relative optical density) was analyzed using AlphaEaseFC 4.0. In order to account for potential variations in protein estimation and sample loading, expression of each protein was compared to that of $\alpha$-tubulin in each sample. Tubulins are abundant cytoskeletal proteins that are highly expressed in brain and $\alpha$-tubulin in particular is known to show stabilized expression in the adult stage of life. Each blot was stripped in $62.5 \mathrm{mM}$ Tris, 2\% SDS and $100 \mathrm{mM}$ 2-mercaptoethanol (pH 6.7) for $30 \mathrm{~min}$ at $50^{\circ} \mathrm{C}$ and reprobed with an anti- $\alpha$-tubulin antibody and relative optical density (ROD) measured as described above. The values for each sample were then expressed as ROD obtained using $\alpha$-tubulin.

Reverse transcription-PCR. The C6 cells from 25 $\mathrm{cm}^{2}$ culture flask were homogenized in TRI Reagent (Sigma). Briefly, cells were collected by centrifugation at $400 \times \mathrm{g}$ and then lysed in $1 \mathrm{ml}$ of TRI Reagent by repeated pipetting. To ensure complete dissociation of nucleoprotein complexes, samples were allowed to stand for 5 minutes at room temperature, then $0.2 \mathrm{ml}$ of chloroform was added. Sample was tightly covered and shaken vigorously for 15 seconds, and allowed to stand for 15 minutes at room temperature. The resulting mixture was centrifuged at $10000 \times g$ for $15 \mathrm{~min}-$ utes at $4^{\circ} \mathrm{C}$. The aqueous phase was transferred to a fresh tube and $0.5 \mathrm{ml}$ of isopropanol was added and mixed. The sample was allowed to stand for 10 minutes at room temperature and then centrifuged at $12000 \times \mathrm{g}$ 
for 10 minutes at $4^{\circ} \mathrm{C}$. The supernatant was removed and the RNA pellet was washed by adding $1 \mathrm{ml}$ of $75 \%$ ethanol. The sample was vortexed and centrifuged at $7500 \times g$ for 5 minutes at $4^{\circ} \mathrm{C}$. The RNA pellet was briefly dried for 5 minutes in air. An appropriate volume of DEPC water was added and the RNA pellet dissolved with repeated pipetting with a micropipette at $55-60^{\circ} \mathrm{C}$ for $10-15$ minutes.

Total RNA was reverse transcribed according to the manufacturer's instruction. Briefly, the cDNA was amplified in a $50-\mu$ l reaction containing primer pairs (each $1.0 \mu \mathrm{l}$ ): $\beta$-actin (forward primer 5'TCA CCCACACTGTGCCCATCTACGA3', reverse primer 5'CAGCGGAACCGC TCATTGCCAATGG3'); GFAP (forward primer 5'GGCGCTCAATGCTGGCTTCA3', reverse primer 5'TCTGCCTCCAGCCTCAGGT'T3'); HSP70 (forward primer 5'GAGT'TCAAGCGCAAACACAA3', reverse primer 5'CTCAGACT'TGTCGCCAATGA3'); mortalin (forward primer 5'CAGTCTTCTGGTGGATTAAG3', reverse primer 5'ATTAGCACCGTCACGTAACACCTC3'), 10× buffer $(5.0 \mu \mathrm{l})$, cDNA $(2.0 \mu \mathrm{l}), 25$ $\mathrm{mM} \mathrm{MgCl}_{2}(3.0 \mu \mathrm{l}), 10 \mathrm{mM}$ dNTPs $(1.0 \mu \mathrm{l})$, and Taq polymerase $(2.5 \mathrm{U})$. PCR amplification cycles consisted of denaturation at $94^{\circ} \mathrm{C}$ for $1 \mathrm{~min}$, primer annealing at $57^{\circ} \mathrm{C}$ for $45 \mathrm{~s}$ and extension at $72^{\circ} \mathrm{C}$ for $45 \mathrm{~s}$, for a total of 30 cycles followed by final extension at $72^{\circ} \mathrm{C}$ for $5 \mathrm{~min}$. The PCR product was separated by electrophoresis on $2 \%$ agarose gels.

Statistical analysis. Results were expressed as the mean \pm S.E.M. from at least three independent experiments. Data for multiple variable comparisons were analyzed by one-way analysis of variance (ANOVA). For the comparison of significance between groups, Bonferroni test was used according to the statistical program SigmaStat (Jandel Scientific, Chicago, IL, USA).
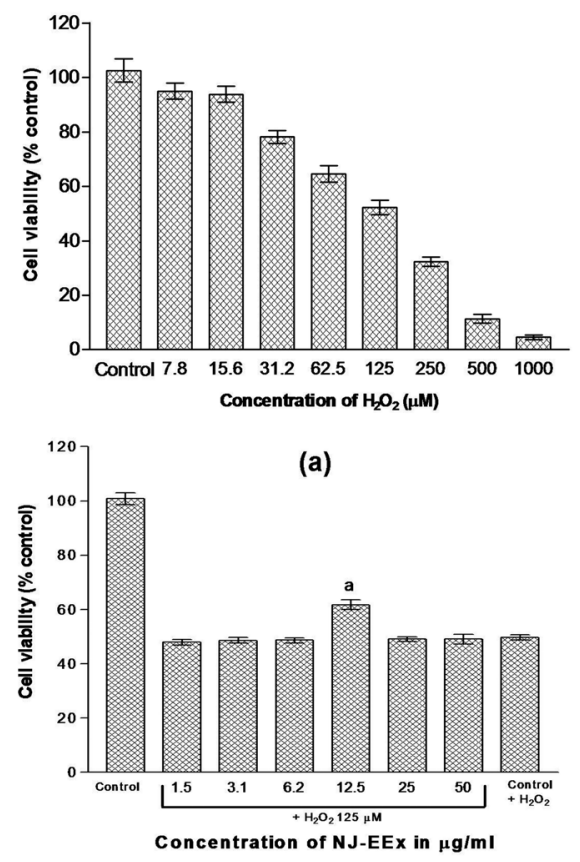

(c)

\section{RESULTS}

\section{NJ-MEx protected C6 glioma cells against $\mathrm{H}_{2} \mathrm{O}_{2}$ cytotoxicity}

In the present study, rat C6 glioma cells were cultured in the presence of NJ-MEx, NJ-EEx or NJ-WEx to determine their protective effect against $\mathrm{H}_{2} \mathrm{O}_{2}$-induced cytotoxicity. The IC50 of $\mathrm{H}_{2} \mathrm{O}_{2}$ for C6 cells was evaluated with MTT mitochondrial function assay (Fig. 1a). A dose dependent cell death was observed and an IC50 concentration of $125 \mu \mathrm{M}$ was selected for further studies. Decrease in cell density with increasing doses of $\mathrm{H}_{2} \mathrm{O}_{2}$ in phase contrast micrographs also supported the MTT results (figure not shown). For cytoprotective effect, C6 cells were treated with NJ-MEx, NJ-EEx or NJ-WEx before subjecting to $\mathrm{H}_{2} \mathrm{O}_{2}$ treatment (IC50 dose). Out of the three extracts of $N$. jatamansi used in the present study, NJ-MEx significantly prevented the $\mathrm{H}_{2} \mathrm{O}_{2}$-induced cell death at $6.2 \mu \mathrm{g} / \mathrm{ml}$ which increased cell viability to $70.7 \pm 6.4 \%$ (Fig. 1b) $(p<0.05)$. NJ-EEx and NJ-WEx also protected the cells at $12.5 \mu \mathrm{g} / \mathrm{ml}$ with cell viability of $58.7 \pm 5.1 \%(p<0.05)$ and $60.2 \pm 5.4 \%(p<0.05)$ (Fig. 1c, 1d). The higher concentrations of NJ-MEx, NJ-EEx and NJ-WEx exhibited cytotoxic effect (data not shown). Because of its highest protective effect, only NJ-MEx was selected for further investigation.

\section{Nature of bioactive components of NJ-MEx}

Preliminary screening for phytochemicals demonstrated the presence of flavonoids, steroids, tannins, triterpenoids, saponins and alkaloids in NJ-MEx (Table 1). In the TLC profile of NJ-MEx generated with the chloroform: methanol (24:1) solvent system, eight spots with
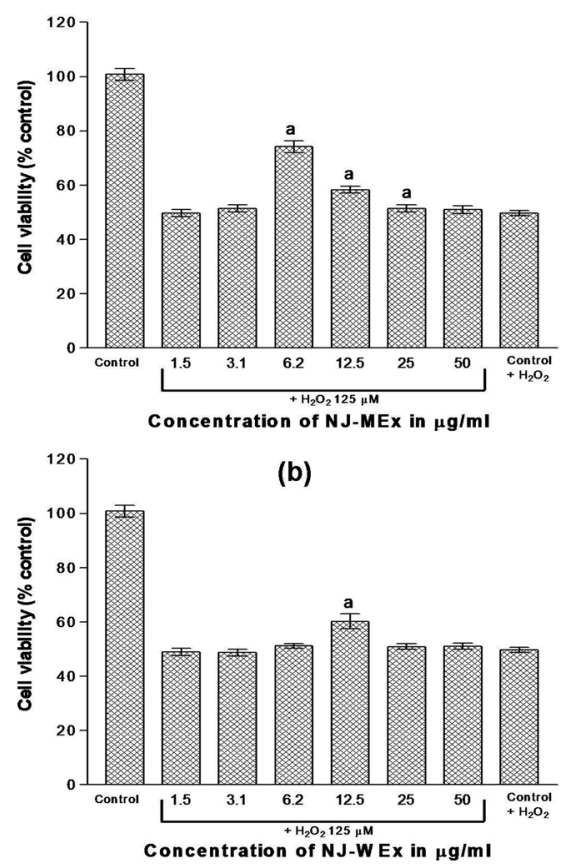

(d)

Figure 1. Cytotoxicity of $\mathrm{H}_{2} \mathrm{O}_{2}$ against $\mathrm{C} 6$ glioma cells

(a) Dose-dependent cytotoxic effect of $\mathrm{H}_{2} \mathrm{O}_{2}$ on $\mathrm{C} 6$ glioma cell viability. Neuroprotective assay of $\mathrm{N}$. jatamansi extracts against $\mathrm{H}_{2} \mathrm{O}_{2} \mathrm{cy}-$ totoxicity (b-d). (b) Effect of pretreatment with NJ-MEx on $\mathrm{H}_{2} \mathrm{O}_{2}$-induced cytotoxicity (c) Effect of pretreatment with $\mathrm{NJ}$-EEx on $\mathrm{H}_{2} \mathrm{O}_{2}$-induced cytotoxicity (d) Effect of pretreatment with NJ-WEx on $\mathrm{H}_{2} \mathrm{O}_{2}$-induced cytotoxicity. Glial cell viability was measured using MTT assay after $24 \mathrm{~h}$ of incubation with $\mathrm{H}_{2} \mathrm{O}_{2}$. The data represents mean \pm S.E.M. from four independently experiments. a, Statistically significant difference between $\mathrm{H}_{2} \mathrm{O}_{2}$ cultures and NJ-MEx $+\mathrm{H}_{2} \mathrm{O}_{2}$ cultures. 


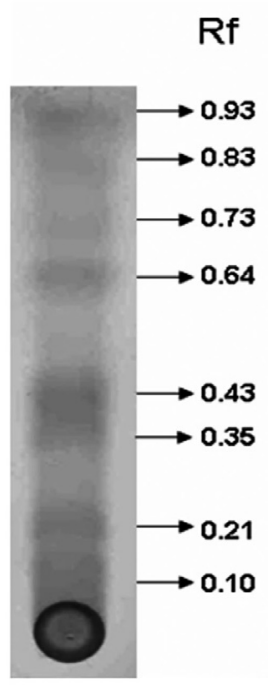

Figure 2. Analysis of NJ-MEx by thin layer chromatography. Chloroform: methanol (24:1) solvent system revealed eight different spots. These spots were visualized using iodine vapors.

$R_{\mathrm{f}}$ values of $0.10,0.21,0.35,0.43,0.64,0.73,0.83$ and 0.93 were observed (Fig. 2).

Effect of NJ-MEx and $\mathrm{H}_{2} \mathrm{O}_{2}$ treatment on the activities of Cu-ZnSOD, Gpx and catalase and the content of GSH and LPX

The activities of $\mathrm{Cu}-\mathrm{ZnSOD}$, catalase, GPx, and the level of GSH and LPx observed in five independent experiments are shown in Table 2 . The activity of catalase was significantly reduced in $\mathrm{H}_{2} \mathrm{O}_{2}$-treated cultures as compared to control $(p<0.05)$. A significant increase of catalase activity was observed in NJ-MEx cultures in comparison to control $(p<0.05)$. Further, the activity of catalase was significantly higher in NJ-MEx $+\mathrm{H}_{2} \mathrm{O}_{2}$ cultures with respect to $\mathrm{H}_{2} \mathrm{O}_{2}$ cultures $(p<0.05)$. A similar trend was observed for $\mathrm{Cu}-\mathrm{ZnSOD}$, i.e., it was significantly decreased in $\mathrm{H}_{2} \mathrm{O}_{2}$ cultures compared to control $(p<0.05)$. NJ-MEx treatment significantly increased the $\mathrm{Cu}-\mathrm{ZnSOD}$ activity in comparison to control $(p<0.05)$. The $\mathrm{Cu}-\mathrm{ZnSOD}$ activity was higher in the NJMEx $+\mathrm{H}_{2} \mathrm{O}_{2}$ than in the $\mathrm{H}_{2} \mathrm{O}_{2}$ cultures.

The activity of GPx was found to decrease significantly $(\phi<0.05)$ following $\mathrm{H}_{2} \mathrm{O}_{2}$ treatment. However, NJ-MEx pretreatment of $\mathrm{H}_{2} \mathrm{O}_{2}$ cultures significantly increased GPx activity as compared to control cultures $(p<0.05)$.

The $\mathrm{H}_{2} \mathrm{O}_{2}$ cultures had a significantly lower level of GSH as compared to control $(p<0.05)$. In NJ-MEx cultures, GSH level increased considerably $(\phi<0.05)$ as
Table 1. Analysis of phytochemicals in NJ-MEx

\begin{tabular}{ll}
\hline Phytochemicals & NJ-MEx \\
\hline Flavonoids & + \\
Steroids & + \\
Tannins & + \\
Anthroquinones & - \\
Triterpenoids & + \\
Amino acids & - \\
Saponins & + \\
Phytosterols & - \\
Alkaloids & + \\
\hline
\end{tabular}

"+", presence; "-", absence.

compared to control. An increased GSH content was also observed in $\mathrm{NJ}-\mathrm{MEx}+\mathrm{H}_{2} \mathrm{O}_{2}$ cultures compared to $\mathrm{H}_{2} \mathrm{O}_{2}$ cultures $(\phi<0.05)$, indicating a protective effect of NJ-MEx.

A considerable increase in lipid peroxidation was observed in $\mathrm{H}_{2} \mathrm{O}_{2}$ cultures as compared to control $(p<0.05)$, but a pretreatment with NJ-MEx decreased lipid peroxidation significantly $(p<0.05)$. The NJ-MEx treatment also decreased lipid peroxidation in cultures not subjected to $\mathrm{H}_{2} \mathrm{O}_{2}$ treatment, confirming its antioxidant effect.

\section{Effect of NJ-MEx on mRNA and protein expressions of GFAP in $\mathrm{C} 6$ cells exposed to $\mathrm{H}_{2} \mathrm{O}_{2}$}

GFAP is an intermediate filament protein specific to glial cells in the CNS. We examined expression of GFAP by immunofluorescence (Fig. 3a-d). The increased expression of GFAP in $\mathrm{H}_{2} \mathrm{O}_{2}$ cultures was attenuated be pretreatment with NJ-MEx $(p<0.05)$ (Fig. 3g). Expression of GFAP remained unchanged in NJ-MEx cultures, indicating no stress. GFAP and $\alpha$ tubulin labeling in C6 glioma cell cultures are shown in Fig. 3e. The expression of GFAP normalized against $\alpha$-tubulin is illustrated in Fig. 3h. The cytoprotection was confirmed at the protein level by western blotting. The increase in GFAP due to $\mathrm{H}_{2} \mathrm{O}_{2}$, indicating oxidative stress, was alleviated considerably with NJ-MEx pretreatment $(p<0.05)$. The protection due to NJ-MEx was further confirmed at the transcript level using RTPCR (Fig. 3f, i). The GFAP mRNA level was significantly lower in NJ-MEx $+\mathrm{H}_{2} \mathrm{O}_{2}$ cultures than in $\mathrm{H}_{2} \mathrm{O}_{2}$ cultures $(p<0.05)$. No significant difference in GFAP expression was observed between control and NJ-MEx cultures using immunofluorescence, western blotting or RT-PCR.

Table 2. Effect of cytoprotective activity of NJ-MEx on antioxidant scavenger system in C6 glioma cell cultures.

\begin{tabular}{|c|c|c|c|c|c|}
\hline Groups & Cu-Zn-SOD (U g tissue $\left.{ }^{-1}\right)$ & GPx $\left(U \mathrm{~g}\right.$ tissue $\left.{ }^{-1}\right)$ & 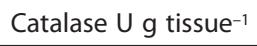 & GSH (mg g tissue ${ }^{-1}$ ) & $\operatorname{LPx}\left(\mathrm{mg} \mathrm{dl}^{-1}\right)$ \\
\hline Control & $13.29 \pm 0.79$ & $14.23 \pm 0.86$ & $2.18 \pm 0.39$ & $2.95 \pm 0.19$ & $10.26 \pm 0.57$ \\
\hline N. jatamansi & $14.54 \pm 1.56^{\mathrm{a}}$ & $15.86 \pm 1.05^{\mathrm{a}}$ & $2.38 \pm 0.45^{\mathrm{a}}$ & $3.16 \pm 0.35^{\mathrm{a}}$ & $8.09 \pm 0.31^{a}$ \\
\hline $\mathrm{H}_{2} \mathrm{O}_{2}$ & $7.63 \pm 0.96^{b}$ & $8.59 \pm 0.72^{b}$ & $1.30 \pm 0.34^{b}$ & $1.89 \pm 0.18^{b}$ & $18.49 \pm 0.68^{b}$ \\
\hline N. jatamansi $+\mathrm{H}_{2} \mathrm{O}_{2}$ & $10.56 \pm 0.84^{c d}$ & $12.93 \pm 0.95^{\mathrm{cd}}$ & $1.89 \pm 0.28^{c d}$ & $2.76 \pm 0.15^{\mathrm{cd}}$ & $14.82 \pm 0.43^{c d}$ \\
\hline
\end{tabular}

The data represents mean \pm S.E.M. of activities of enzymes, and reduced glutathione and lipid peroxidation content measured in homogenates obtained from cells of culture dishes $(n=5)$ derived from three independently prepared cultures. The values having $P<0.05$ are considered significant. a, Statistically significant change in CP-MEx treated cultures with respect to control cultures; ${ }^{b}$, statistically significant change in $\mathrm{H}_{2} \mathrm{O}_{2}$ treated cultures with respect to the control cultures; c, statistically significant change in CP-MEX $+\mathrm{H}_{2} \mathrm{O}_{2}$ treated cultures with respect to the CP-MEx treated cultures; ${ }^{d}$, statistically significant change in $\mathrm{H}_{2} \mathrm{O}_{2}$ treated cultures with respect to the $\mathrm{CP}-\mathrm{MEx}+\mathrm{H}_{2} \mathrm{O}_{2}$ treated cultures; e, statistically significant change in Quercetin $+\mathrm{H}_{2} \mathrm{O}_{2}$ treated cultures with respect to the $\mathrm{H}_{2} \mathrm{O}_{2}$ treated cultures. 


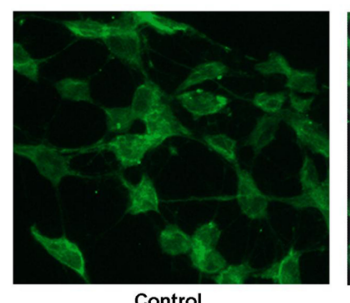

Control

(a)

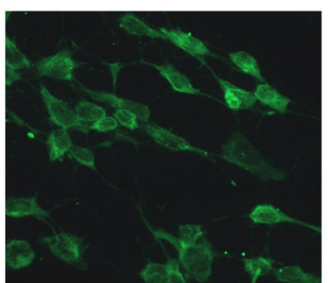

NJ-MEx $6.2 \mu \mathrm{g} / \mathrm{ml}$

(b)

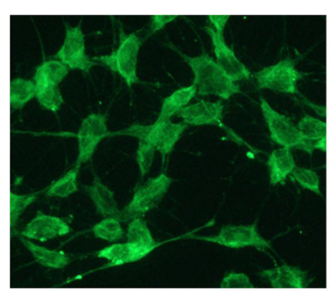

$\mathrm{H}_{2} \mathrm{O}_{2}(125 \mu \mathrm{M})+\mathrm{NJ}-M E x(6.2 \mu \mathrm{g} / \mathrm{ml})$

(c)

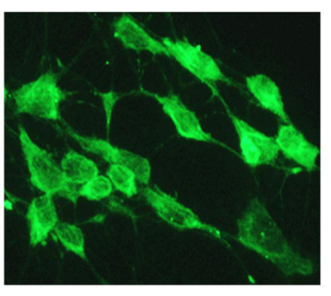

$\mathrm{H}_{2} \mathrm{O}_{2}(125 \mu \mathrm{M})$

(d)
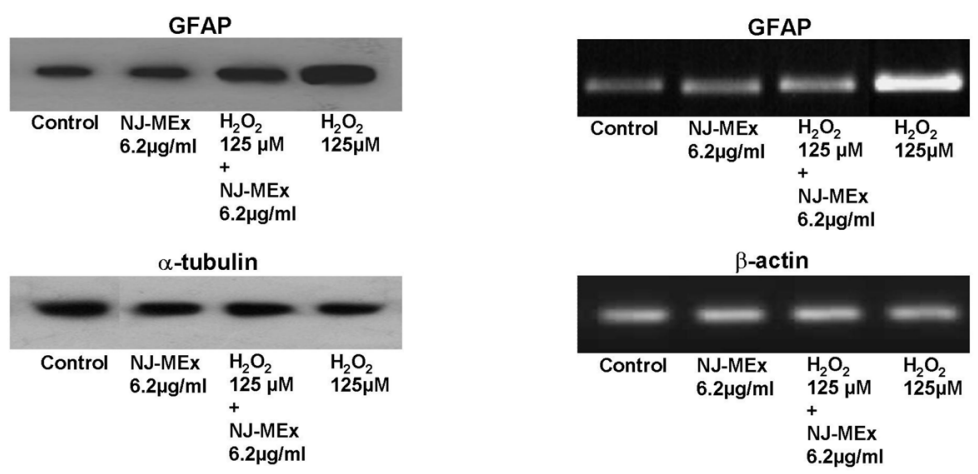

(e)

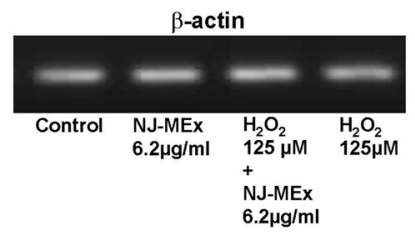

(f)

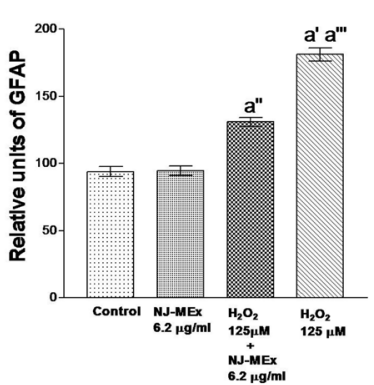

(g)

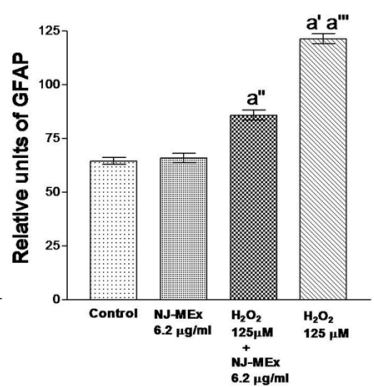

(h)

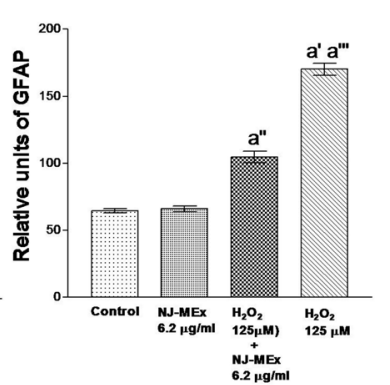

(i)

Figure 3. Localization of GFAP in C6 Glioma cells by immunofluorescence (a-d).

(a) Untreated control (b) NJ-MEx treated (c) NJ-MEx $+\mathrm{H}_{2} \mathrm{O}_{2}$ treated (d) $\mathrm{H}_{2} \mathrm{O}_{2}$ treated. Cells grown on coverslips ( $\mathrm{n}=4$ ) for 4 days were fixed and stained for GFAP (Alexa Fluor 488) immunoreactivity.

Western blotting and Representative reverse transcription-polymerase chain reaction (RT-PCR) of GFAP (e-f).

(e) Representative western blot hybridization signals using antibodies specific for GFAP and a-tubulin from untreated control, NJ-MEx treated, NJ-MEx $+\mathrm{H}_{2} \mathrm{O}_{2}$ treated, $\mathrm{H}_{2} \mathrm{O}_{2}$ treated cultures. (f) Representative reverse transcription-polymerase chain reaction (RT-PCR) showing GFAP and $\beta$-actin expression in untreated control, NJ-MEx treated, NJ-MEx $+\mathrm{H}_{2} \mathrm{O}_{2}$ treated, $\mathrm{H}_{2} \mathrm{O}_{2}$ treated C6 glioma cells.

Relative intensity analyses of GFAP in immunofluorescence, western blot hybridization and RT-PCR (g-i)

(g) Relative intensity of GFAP immunofluorescence performed by ImageJ $1.44 \mathrm{p}$. (h) Relative optical density of GFAP in western blot hybridization for each group expressed as percentage of a-tubulin (i) Relative optical density of GFAP expression in RT-PCR for each group expressed as percentage of $\beta$-actin. Relative units of GFAP were calculated for immunofluorescence by ImageJ $1.44 p$ and for western blotting and RT-PCR by AlphaEaseFC 4.0. The values having $p<0.05$ are considered significant. a', statistically significant difference $\mathrm{H}_{2} \mathrm{O}_{2}$ treated cultures and control cultures; a", statistically significant difference between NJ-MEx $+\mathrm{H}_{2} \mathrm{O}_{2}$ treated cultures and NJ-MEx treated cultures; a'", statistically significant difference between $\mathrm{H}_{2} \mathrm{O}_{2}$-treated cultures and NJ-MEx $+\mathrm{H}_{2} \mathrm{O}_{2}$ treated cultures.

\section{Effect of NJ-MEx on HSP70 expression in C6 cells exposed to $\mathrm{H}_{2} \mathrm{O}_{2}$}

After a variety of nervous system insults, HSP70 is synthesized at especially high levels and is present in the cytosol, nucleus and endoplasmic reticulum (Giffard et al., 2004). We examined C6 cells for HSP70 expression following exposure to $\mathrm{H}_{2} \mathrm{O}_{2}$ in the presence or absence of NJ-MEx using immunofluorescence, western blotting and RT-PCR (Fig. 4a-f). The Protective effect of NJ-MEx was confirmed by all three parameters as the increased level of HSP70 in $\mathrm{H}_{2} \mathrm{O}_{2}$ cultures was significantly reduced with pretreatment of NJ-MEx $(p<0.05)$ (Fig. 4 g-i).

\section{Effect of NJ-MEx on mRNA and protein level of mortalin in $\mathrm{C} 6$ cells treated with $\mathrm{H}_{2} \mathrm{O}_{2}$}

Mortalin is a heat-shock cognate protein whose level has been reported to increase under the stress (Taurin et al., 2002). To study the perinuclear expression of mortalin, C6 glioma cells were subjected to immunofluorescence, western blotting and RT-PCR (Fig. 5a-f). The level of mortalin was significantly higher in $\mathrm{H}_{2} \mathrm{O}_{2}$ cultures as compared to control (Fig. 5g) $(p<0.05)$. We observed a reduction of the level of mortalin in NJ-MEx pretreated $\mathrm{H}_{2} \mathrm{O}_{2}$ cultures by immunofluorescence, clearly indicating protection (Fig. 5g) $(p<0.05)$. There was no significant difference in mortalin expression between control and 


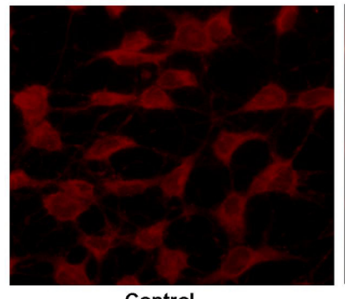

(a)

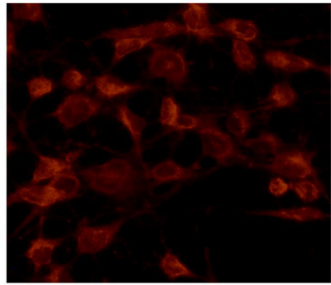

NJ-MEx $(6.2 \mu \mathrm{g} / \mathrm{ml})$

(b)

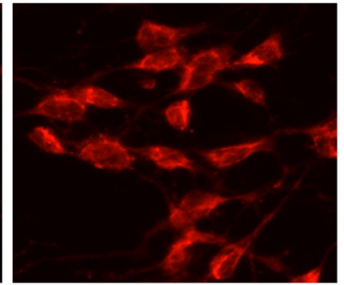

$\mathrm{H}_{2} \mathrm{O}_{2}(125 \mu \mathrm{M})+\mathrm{NJ}-\mathrm{MEx}(6.2 \mu \mathrm{g} / \mathrm{ml})$

(c)

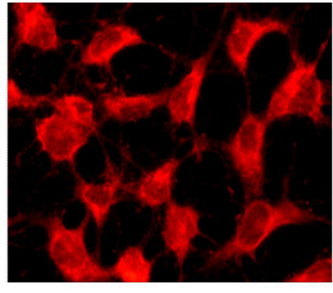

$\mathrm{H}_{2} \mathrm{O}_{2}(125 \mu \mathrm{M})$

(d)
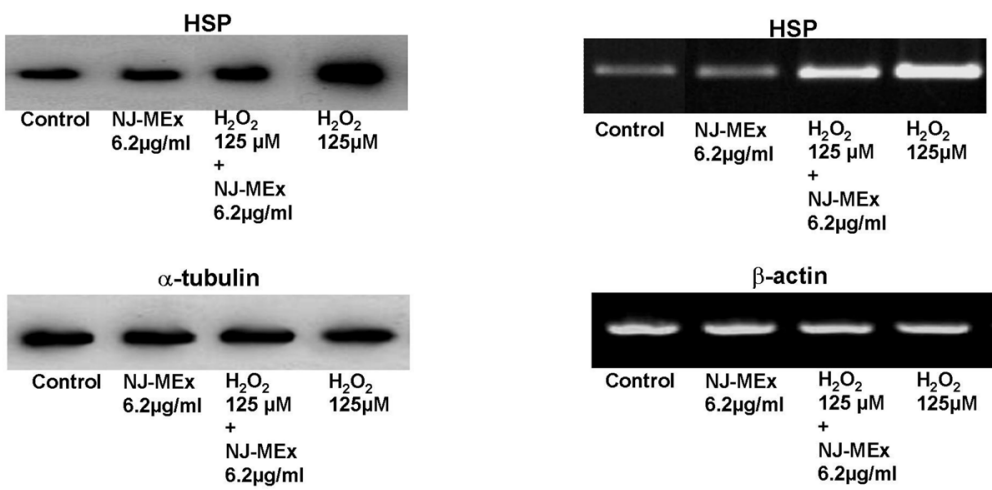

(e)

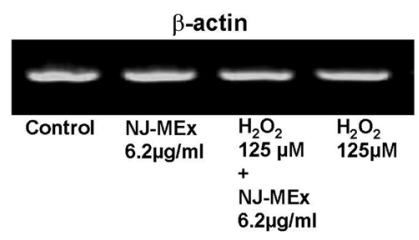

(f)

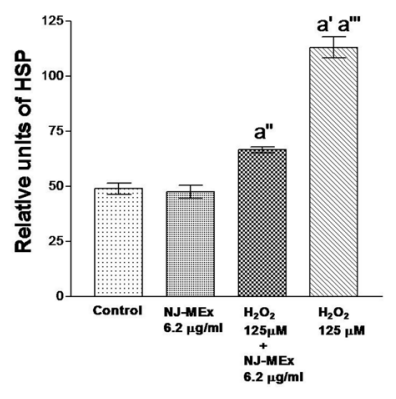

(g)

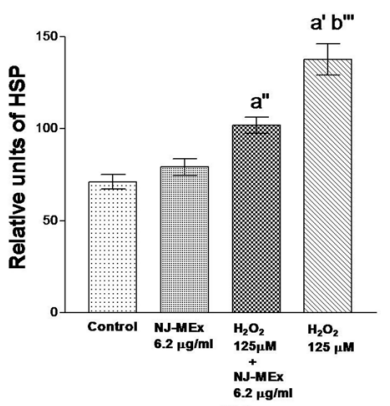

(h)

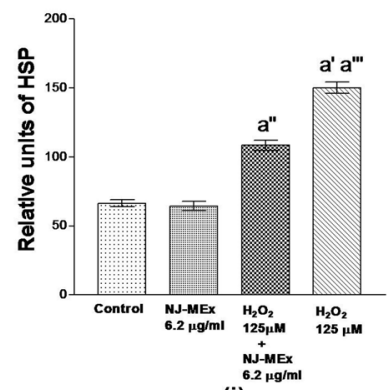

(i)

Figure 4. Distribution of HSP70 in C6 Glioma cells by immunofluorescence (a-d).

(a) Untreated control (b) NJ-MEx treated (c) NJ-MEx $+\mathrm{H}_{2} \mathrm{O}_{2}$ treated (d) $\mathrm{H}_{2} \mathrm{O}_{2}$ treated. Cells grown on coverslips ( $\mathrm{n}=4$ ) for 4 days were fixed and stained for HSP70 (Alexa Fluor 488) immunoreactivity.

Western blotting and Representative reverse transcription-polymerase chain reaction (RT-PCR) of HSP70 (e-f)

(e) Representative western blot hybridization signals using antibodies specific for HSP70 and a-tubulin from untreated control, NJ-MEx treated, NJ-MEx $+\mathrm{H}_{2} \mathrm{O}_{2}$ treated, $\mathrm{H}_{2} \mathrm{O}_{2}$ treated cultures. (f) Representative reverse transcription-polymerase chain reaction (RT-PCR) showing HSP70 and $\beta$-actin expression in untreated control, NJ-MEx treated, NJ-MEx $+\mathrm{H}_{2} \mathrm{O}_{2}$ treated, $\mathrm{H}_{2} \mathrm{O}_{2}$ treated C6 glioma cells.

Relative intensity analyses of HSP70 in immunofluorescence, western blot hybridization and RT-PCR (g-i).

(g) Relative intensity of HSP70 immunofluorescence performed by ImageJ 1.44p. (h) Relative optical density of HSP70 in western blot hybridization for each group expressed as percentage of a-tubulin (i) Relative optical density of HSP70 expression in RT-PCR for each group expressed as percentage of $\beta$-actin. Relative units of HSP70 were calculated for immunofluorescence by ImageJ $1.44 p$ and for western blotting and RT-PCR by AlphaEaseFC 4.0. The values having $p<0.05$ are considered significant. a', statistically significant difference $\mathrm{H}_{2} \mathrm{O}_{2}$ treated cultures and control cultures; a", statistically significant difference between NJ-MEx $+\mathrm{H}_{2} \mathrm{O}_{2}$ treated cultures and NJ-MEx treated cultures; a"', statistically significant difference between $\mathrm{H}_{2} \mathrm{O}_{2}$-treated cultures and NJ-MEx $+\mathrm{H}_{2} \mathrm{O}_{2}$ treated cultures.

NJ-MEx treated cells (Fig. 5g). The data from western blotting and RT-PCR further supported the protective effect of NJ-MEx (Fig. 5h, i) $(p<0.05)$.

\section{DISCUSSION}

Oxidative stress occurs when the cellular homeostasis, normally involving a fine balance between free radical generation and their detoxification by cellular antioxidants, is disturbed. Earlier studies have pointed to oxidative stress as a major reason for neuronal cell death leading to neurodegenerative disorders like ischemia, PD, AD and HD (Axelsen et al., 2011; Caviness et al., 2011; Chen, 2011; Doeppner and Hermann, 2010). The anti- oxidant machinery of the cell (natural antioxidant molecules and enzymes) scavenges and reduces free radicals production, but sometimes it may not be sufficient to manage this stress, initiating extensive damage to biological macromolecules, proteins, nucleic acids and lipids, ultimately leading to tissue damage (Halliwell, 2012; Halliwell \& Gutteridge, 1999). Therefore, inducing antioxidant defense machinery through herbal means would be an effective strategy to prevent this harmful oxidative injury.

Nardostachys jatamansi extracts have earlier been shown to have antioxidant properties with chemical antioxidant assays (Rasheed et al., 2010; Sharma \& Singh, 2012). However, there is a need to authenticate this activity at 


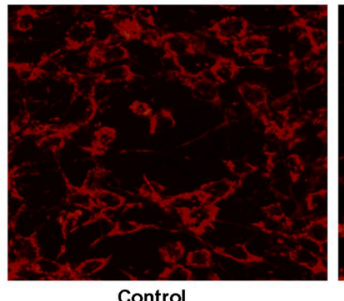

Control

(a)

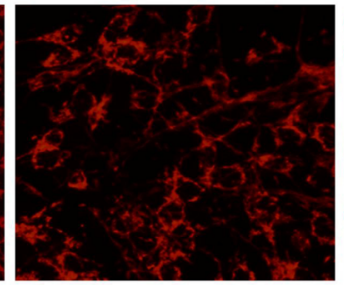

NJ-MEx $(6.2 \mu \mathrm{g} / \mathrm{ml})$

(b)

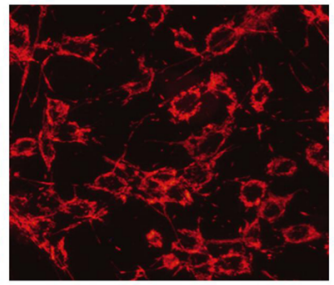

$\mathrm{H}_{2} \mathrm{O}_{2}(125 \mu \mathrm{M})+\mathrm{NJ}-M E x(6.2 \mu \mathrm{g} / \mathrm{ml})$

(c)

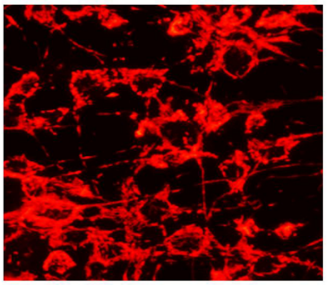

$\mathrm{H}_{2} \mathrm{O}_{2}(125 \mu \mathrm{M})$

(d)
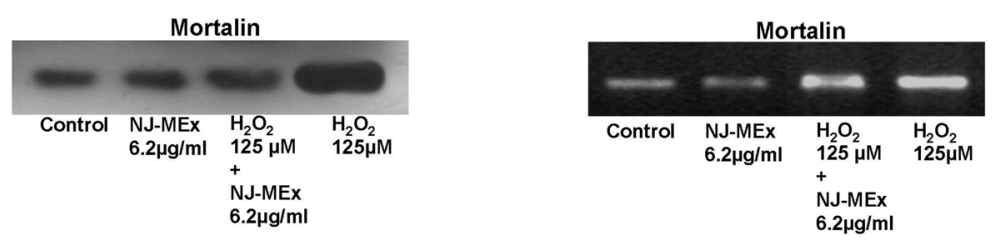

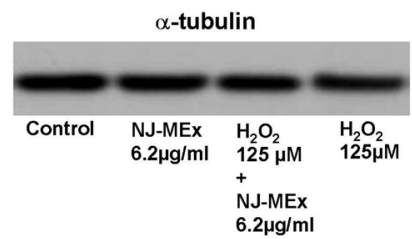

(e)

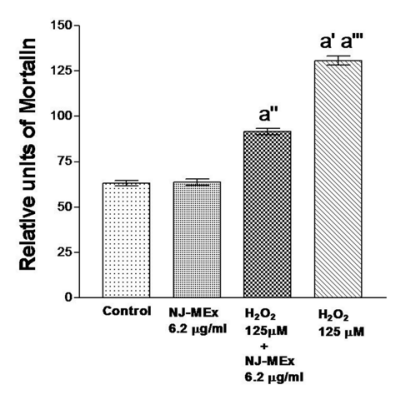

(g)

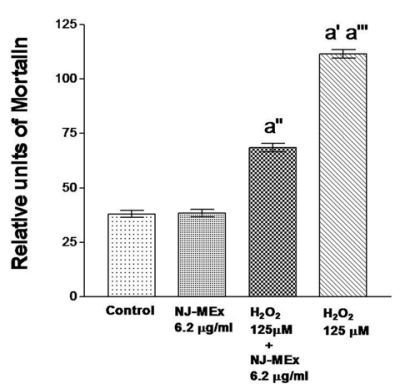

(h)

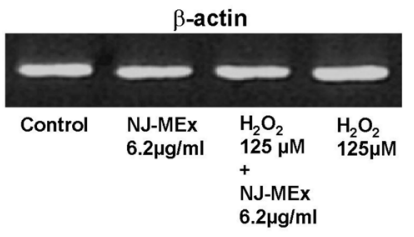

(f)

Figure 5. Localization of mortalin in $\mathrm{C} 6$ Glioma cells by immunofluorescence (a-d).

(a) Untreated control (b) NJ-MEx treated (c) NJ-MEx $+\mathrm{H}_{2} \mathrm{O}_{2}$ treated (d) $\mathrm{H}_{2} \mathrm{O}_{2}$ treated. Cells grown on coverslips $(n=4)$ for 4 days were fixed and stained for mortalin (Alexa Fluor 488) immunoreactivity.

Western blotting and Representative reverse transcription-polymerase chain reaction (RT-PCR) of mortalin (e-f).

(e) Representative western blot hybridization signals using antibodies specific for mortalin and a-tubulin from untreated control, NJ-MEx treated, NJ-MEx $+\mathrm{H}_{2} \mathrm{O}_{2}$ treated, $\mathrm{H}_{2} \mathrm{O}_{2}$ treated cultures. (f) Representative reverse transcription-polymerase chain reaction (RT-PCR) showing mortalin and $\beta$-actin expression in untreated control, NJ-MEx treated, NJ-MEx $+\mathrm{H}_{2} \mathrm{O}_{2}$ treated, $\mathrm{H}_{2} \mathrm{O}_{2}$ treated C6 glioma cells.

Relative intensity analyses of mortalin in immunofluorescence, western blot hybridization and RT-PCR (g-i).

(g) Relative intensity of mortalin immunofluorescence performed by ImageJ 1.44p. (h) Relative optical density of mortalin in western blot hybridization for each group expressed as percentage of a-tubulin (i) Relative optical density of mortalin expression in RT-PCR for each group expressed as percentage of $\beta$-actin. Relative units of mortalin were calculated for immunofluorescence by ImageJ $1.44 \mathrm{p}$ and for western blotting and RT-PCR by AlphaEaseFC 4.0. The values having $p<0.05$ are considered significant. a', statistically significant difference $\mathrm{H}_{2} \mathrm{O}_{2}$ treated cultures and control cultures; a", statistically significant difference between NJ-MEx $+\mathrm{H}_{2} \mathrm{O}_{2}$ treated cultures and NJ-MEx treated cultures; a"', statistically significant difference between $\mathrm{H}_{2} \mathrm{O}_{2}$-treated cultures and NJ-MEx $+\mathrm{H}_{2} \mathrm{O}_{2}$ treated cultures.

the cellular level by quantitating stress markers and the activity of antioxidant machinery. Therefore, the present study was planned to examine the antioxidant activity of N. jatamansi extracts at a cellular level. Cytoprotection against oxidative stress produced by $\mathrm{H}_{2} \mathrm{O}_{2}$ in $\mathrm{C} 6$ glioma cell line was used as a cellular antioxidant assay for plant extracts. The possible mechanism of cytoprotection was also addressed by evaluating expression of selected proteins known to be induced by oxidative stress.

$\mathrm{H}_{2} \mathrm{O}_{2}$ is well known to act as a potent inducer of reactive oxygen species (ROS) and capable of inducing cell injury both in vitro and in vivo (Kim et al., 2012; Terashvili et al., 2012). Particularly, in C6 glioma cells, $\mathrm{H}_{2} \mathrm{O}_{2}$ is known to induce oxidative damage, leading to lipid peroxidation, ROS generation, GSH depletion and reduction in antioxidant enzymes (catalase, superoxide dismutase and glutathione peroxidase) activity preceding cell death (Brenner et al., 2010; Gulden et al., 2010). Hence, $\mathrm{H}_{2} \mathrm{O}_{2}$ has been extensively used in studying the effects of antioxidant phytochemicals in C6 glioma cells (Brenner et al., 2010; Gulden et al., 2010). In the present work, C6 glioma cells were treated with $\mathrm{H}_{2} \mathrm{O}_{2}$ at a concentration of $125 \mu \mathrm{M}$ (IC50 concentration, Fig. 1a). This concentration was further used in antioxidant assays and expression analysis of GFAP, HSP and mortalin. To ensure that there is no induction of stress proteins, only a non-toxic concentration of the plant extract was chosen for key experiments. The results demonstrated 
that none of the $N$. jatamansi extracts assayed produced a toxic effect (after $24 \mathrm{~h}$ of treatment) at concentrations of $50 \mu \mathrm{g} / \mathrm{ml}$ or less (Fig. 1b-d).

NJ-EEx and NJ-WEx had very low cytoprotective effect, whereas NJ-MEx exhibited a potent cytoprotective activity against $\mathrm{H}_{2} \mathrm{O}_{2}$-induced oxidative injury. Such cytoprotection is in accordance with earlier studies on the antioxidant potential of N. jatamansi (Rasheed et al., 2010; Sharma \& Singh, 2012; Subashini et al., 2007) Beside N. jatamansi extracts, Ginkgo biloba and Ashwagandha leaf extracts have also been reported to have cytoprotective effect against $\mathrm{H}_{2} \mathrm{O}_{2}$-induced oxidative damage in glial cells (Altiok et al., 2006; Konar et al., 2011).

The majority of ROS are normally produced during oxidative processes happening in live cells. To combat this stress, cells have a battery of antioxidant enzymes and antioxidant molecules such as glutathione to scavenge superoxide radical and hydrogen peroxide. If ROS go un-scavenged, impairment of physiological functions occurs, ultimately leading to cell death and tissue damage (Halliwell, 2012; Halliwell \& Gutteridge, 1999). Catalase, SOD and GPx, along with other antioxidants of enzymatic and non-enzymatic nature, play crucial function in saving the cell from oxidative damage. In this study, a clear increase in lipid peroxidation was linked with $\mathrm{H}_{2} \mathrm{O}_{2}$ dose. Further, considerable reduction in catalase, SOD, GSH and GPx level was observed following treatment with $\mathrm{H}_{2} \mathrm{O}_{2}$, signifying damage in internal antioxidant defense system of the cell. However, pretreatment of C6 cells with NJ-MEx greatly mitigated the $\mathrm{H}_{2} \mathrm{O}_{2}$ effects. These findings apparently indicate protection of the endogenous antioxidant defense system.

To reveal the possible cytoprotective mechanism of NJ-MEx, immunofluorescence, western blotting and RTPCR were used to examine the expression of three stress indicator proteins of the cell, GFAP, HSP70 and mortalin.

GFAP is a type-III intermediate filament, first identified in astrocytes (Eng, 1985). It is highly conserved throughout vertebrate evolution, suggesting that it plays a critical function in the central nervous system. In the current study, elevated expression of GFAP upon $\mathrm{H}_{2} \mathrm{O}_{2}$ exposure could be attributed to reactive gliosis and its stimulation. Augmented levels of intermediate filament proteins, particularly GFAP by reactive astrocytes are the best known characteristics of reactive gliosis. Such upregulation in intermediary filaments is known to occur in response to most brain injuries (Pekny \& Nilsson, 2005). Such variation in protein levels is primarily controlled by transcriptional regulation (Landry et al., 1990). Our observations illustrated that NJ-MEx directly down-regulated GFAP expression at both protein and mRNA levels in C6 glioma cells, indicating a possible mechanism of the cytoprotective effect of the extract in C6 cells.

Heat shock proteins are essential components of the response to a wide variety of toxic conditions and have attracted a great interest being essential for cell survival. The synthesis of HSP in mammalian cells is activated not only under heat shock, but also in the conditions of disturbed cellular homeostasis, heavy metal toxicity and drug cytotoxicity (Calabrese et al., 2001; Colombrita et al., 2003; Scapagnini et al., 2002). HSP70 is known to play a protective role in animal and cellular models of neurotoxicity such as ischemia (Sauer et al., 2001), trauma (Schipke et al., 2001) and Alzheimer's disease (Chow \& Brown, 2007). Increased HSP70 expression of $\mathrm{H}_{2} \mathrm{O}_{2}$ treated cultures was significantly attenuated by $\mathrm{NJ}-\mathrm{MEx}$ pretreatment, substantiating its protective role.
In normal cell mortalin is scattered throughout the cytoplasm but its localization changes in immortal cells to the perinuclear region (Wadhwa et al., 1993). An enhancement of mortalin expression is a type of stress response or an adaptive response to $\mathrm{H}_{2} \mathrm{O}_{2}$ treatment (Osorio et al., 2007). Results in the present study show a significant increase in the mortalin expression, following $\mathrm{H}_{2} \mathrm{O}_{2}$ exposure. The pre-treatment of $\mathrm{H}_{2} \mathrm{O}_{2}$-treated cultures with NJ-MEx significantly reduced mortalin expression.

Glioblastoma is the most common of brain tumours and is very difficult to treat. Despite the use of different treatment regimens, which include surgery, radiotherapy, and chemotherapy, most patients do not live longer than a year after diagnosis. Based on our present data, we suggest the use of NJ-MEx and its constituents as effective glioma therapy.

\section{CONCLUSION}

Of the extracts of $N$. jatamansi, only NJ-MEx exhibited significant cytoprotective activity against $\mathrm{H}_{2} \mathrm{O}_{2}$-induced oxidative damage by induction of endogenous antioxidant enzymes, increase in glutathione level and prevention of direct membrane damage due to lipid peroxidation. These observations were further substantiated by the reduction in the level of GFAP, HSP70 and mortalin with pretreatment of C6 cells with NJ-MEx before subjecting to $\mathrm{H}_{2} \mathrm{O}_{2}$. Further study is needed to investigate other cytoprotective proteins which could be involved in the cytoprotection mechanism.

\section{Conflict of interest}

The authors have declared no conflicts of interest.

\section{Acknowledgement}

The study was supported by grants from the University Grants Commission-College for Potential for Excellence, New Delhi and Department of Science and Technology (DST), Ministry of Science and Technology, Government of India, New Delhi. One of the authors, Ms. Kshitija Dhuna, is supported by a Senior Research Fellowship grant from the Council of Scientific and Industrial Research (CSIR), New Delhi, India. Mr. Gaurav Bhatia, project fellow, is supported by DST-SERC Fast Track Scheme by DST, New Delhi.

\section{REFERENCES}

Aebi H (1984) Catalase in vitro. Methods Enzymol 105: 121-126.

Ahmad M, Yousuf S, Khan MB, Hoda MN, Ahmad AS, Ansari MA, Ishrat T, Agrawal AK, Islam F (2006) Attenuation by Nardostachys jatamansi of 6-hydroxydopamine-induced parkinsonism in rats: behavioral, neurochemical, and immunohistochemical studies. Pharmacol Biochem Behav 83: 150-160.

Altiok N, Ersoz M, Karpuz V, Koyuturk M (2006) Ginkgo biloba extract regulates differentially the cell death induced by hydrogen peroxide and simvastatin. Neurotoxicology 27: 158-163.

Axelsen PH, Komatsu H, Murray IV (2011) Oxidative stress and cell membranes in the pathogenesis of Alzheimer's disease. Physiology (Bethesda) 26: 54-69.

Bayir H, Kagan VE, Clark RS, Janesko-Feldman K, Rafikov R, Huang Z, Zhang X, Vagni V, Billiar TR, Kochanek PM (2007) Neuronal NOS-mediated nitration and inactivation of manganese superoxide dismutase in brain after experimental and human brain injury. $J$ Neurochem 101: 168-181.

Benda P, Lightbody J, Sato G, Levine L, Sweet W (1968) Differentiated rat glial cell strain in tissue culture. Science 161: 370-371.

Bjornstedt M, Xue J, Huang W, Akesson B, Holmgren A (1994) The thioredoxin and glutaredoxin systems are efficient electron donors 
to human plasma glutathione peroxidase. J Biol Chem 269: 29382 29384.

Borniquel S, Valle I, Cadenas S, Lamas S, Monsalve M (2006) Nitric oxide regulates mitochondrial oxidative stress protection via the transcriptional coactivator PGC-1alpha. FASEB J 20: 1889-1891.

Brenner S, Gulden M, Maser E, Seibert H (2010) Lasting effect of preceding culture conditions on the susceptibility of C6 cells to peroxide-induced oxidative stress. Toxicol In Vitro 24: 2090-2096.

Buege JA, Aust SD (1978) Microsomal lipid peroxidation. Methods Enaymol 52: 302-310.

Calabrese V, Scapagnini G, Giuffrida Stella AM, Bates TE, Clark JB (2001) Mitochondrial involvement in brain function and dysfunction: relevance to aging, neurodegenerative disorders and longevity. Neurochem Res 26: 739-764.

Carette J, Lehnert S, Chow TY (2002) Implication of PBP74/mortalin/ GRP75 in the radio-adaptive response. Int J Radiat Biol 78: 183-190.

Caviness JN, Lue L, Adler CH, Walker DG (2011) Parkinson's disease dementia and potential therapeutic strategies. CNS Neurosi Ther 17: 32-44.

Chatterjee A, Basak B, Saha M, Dutta U, Mukhopadhyay C, Banerji J, Konda Y, Harigaya Y (2000) Structure and stereochemistry of nardostachysin, a new terpenoid ester constituent of the rhizomes of Nardostachys jatamansi. J Nat Prod 63: 1531-1533.

Chen CM (2011) Mitochondrial dysfunction, metabolic deficits, and increased oxidative stress in Huntington's disease. Chang Gung Med J 34: 135-152.

Chow AM, Brown IR (2007) Induction of heat shock proteins in differentiated human and rodent neurons by celastrol. Cell Stress Chaperones 12: 237-244.

Colombrita C, Calabrese V, Stella AM, Mattei F, Alkon DL, Scapagnini G (2003) Regional rat brain distribution of heme oxygenase-1 and manganese superoxide dismutase mRNA: relevance of redox homeostasis in the aging processes. Exp Biol Med (Maywood) 228: 517-524.

Doeppner TR, Hermann DM (2010) Free radical scavengers and spin traps - therapeutic implications for ischemic stroke. Best Pract Res Clin Anaesthesiol 24: 511-520.

Dringen R, Kussmaul L, Gutterer JM, Hirrlinger J, Hamprecht B (1999) The glutathione system of peroxide detoxification is less efficient in neurons than in astroglial cells. I Neurochem 72: 2523-2530.

Eng LF (1985) Glial fibrillary acidic protein (GFAP): the major protein of glial intermediate filaments in differentiated astrocytes. I Neuroimmunol 8: 203-214.

Eng LF, Ghirnikar RS (1994) GFAP and astrogliosis. Brain Pathol 4: 229-237.

Giffard RG, Xu L, Zhao H, Carrico W, Ouyang Y, Qiao Y, Sapolsky R, Steinberg G, Hu B, Yenari MA (2004) Chaperones, protein aggregation, and brain protection from hypoxic/ischemic injury. $J$ Exp Biol 207: 3213-3220.

Gulden M, Jess A, Kammann J, Maser E, Seibert H (2010) Cytotoxic potency of $\mathrm{H} 2 \mathrm{O} 2$ in cell cultures: impact of cell concentration and exposure time. Free Radic Biol Med 49: 1298-1305.

Hadari YR, Haring HU, Zick Y (1997) p75, a member of the heat shock protein family, undergoes tyrosine phosphorylation in response to oxidative stress. J Biol Chem 272: 657-662.

Halliwell B (2012) Free radicals and antioxidants: updating a personal view. Nutr Rev 70: 257-265.

Halliwell B, Gutteridge JMC (1999) Free radicals in biology and medicine. Oxford; New York: Clarendon Press; Oxford University Press..

Han D, Sen CK, Roy S, Kobayashi MS, Tritschler HJ, Packer L (1997) Protection against glutamate-induced cytotoxicity in C6 glial cells by thiol antioxidants. Am J Physiol 273: R1771-R1778.

Han X, Pan J, Ren D, Cheng Y, Fan P, Lou H (2008) Naringenin7-O-glucoside protects against doxorubicin-induced toxicity in $\mathrm{H} 9 \mathrm{c} 2$ cardiomyocytes by induction of endogenous antioxidant enzymes. Food Chem Toxicol 46: 3140-3146.

Hansen MB, Nielsen SE, Berg K (1989) Re-examination and further development of a precise and rapid dye method for measuring cell growth/cell kill. J Immunol Methods 119: 203-210.

Harborne JB (1998). Phytochemical methods : a guide to modern techniques of plant analysis. London; New York: Chapman and Hall.

Hertz L, Dringen R, Schousboe A, Robinson SR (1999) Astrocytes: glutamate producers for neurons. I Neurosci Res 57: 417-428.

Katayama S, Ishikawa S, Fan MZ, Mine Y (2007) Oligophosphopeptides derived from egg yolk phosvitin up-regulate gamma-glutamylcysteine synthetase and antioxidant enzymes against oxidative stress in Caco-2 cells. I Agric Food Chem 55: 2829-2835.

Kim HS, Lee K, Kang KA, Lee NH, Hyun JW (2012) Phloroglucinol exerts protective effects against oxidative stress-induced cell damage in SH-SY5Y cells. J Pharmacol Sci 119: 186-192.

Konar A, Shah N, Singh R, Saxena N, Kaul SC, Wadhwa R, Thakur MK (2011) Protective role of Ashwagandha leaf extract and its component withanone on scopolamine-induced changes in the brain and brain-derived cells. PLoS One 6: e27265.

Kono Y (1978) Generation of superoxide radical during autoxidation of hydroxylamine and an assay for superoxide dismutase. Arch Biochem Biophys 186: 189-195.
Landry CF, Ivy GO, Brown IR (1990) Developmental expression of glial fibrillary acidic protein $\mathrm{mRNA}$ in the rat brain analyzed by in situ hybridization. J Neurosci Res 25: 194-203.

Liu B, Gao HM, Wang JY, Jeohn GH, Cooper CL, Hong JS (2002) Role of nitric oxide in inflammation-mediated neurodegeneration. Ann N Y Acad Sci 962: 318-331.

Lyle N, Bhattacharyya D, Sur TK, Munshi S, Paul S, Chatterjee S, Gomes A (2009) Stress modulating antioxidant effect of Nardostachys jatamansi. Indian J Biochem Biophys 46: 93-98.

Maroto R, Perez-Polo JR (1997) BCL-2-related protein expression in apoptosis: oxidative stress versus serum deprivation in PC12 cells. J Neurochem 69: 514-523.

Massa SM, Longo FM, Zuo J, Wang S, Chen J, Sharp FR (1995) Cloning of rat grp75, an hsp70-family member, and its expression in normal and ischemic brain. J Neurosci Res 40: 807-819.

Mitsumoto A, Takeuchi A, Okawa K, Nakagawa Y (2002) A subset of newly synthesized polypeptides in mitochondria from human endothelial cells exposed to hydroperoxide stress. Free Radic Biol Med 32: $22-37$.

Murphy MP (1999) Nitric oxide and cell death. Biochim Biophys Acta 1411: 401-414.

Osorio C, Sullivan PM, He DN, Mace BE, Ervin JF, Strittmatter WJ, Alzate O (2007) Mortalin is regulated by APOE in hippocampus of $\mathrm{AD}$ patients and by human APOE in TR mice. Neurobiol Aging 28: 1853-1862.

Pekny M, Nilsson M (2005) Astrocyte activation and reactive gliosis. Glia 50: 427-434.

Rajdev S, Sharp FR (2000) Stress proteins as molecular markers of neurotoxicity. Toxicol Pathol 28: 105-112.

Rasheed AS, Venkataraman S, Jayaveera KN, Fazil AM, Yasodha KJ, Aleem MA, Mohammed M, Khaja Z, Ushasri B, Pradeep HA, Ibrahim M (2010) Evaluation of toxicological and antioxidant potential of Nardostachys jatamansi in reversing haloperidol-induced catalepsy in rats. Int J Gen Med 3: 127-136.

Rohrdanz E, Schmuck G, Ohler S, Kahl R (2001) The influence of oxidative stress on catalase and MnSOD gene transcription in astrocytes. Brain Res 900: 128-136.

Rutka JT, De Armond SJ, Giblin J, McCulloch JR, Wilson CB, Rosenblum ML (1988) Effect of retinoids on the proliferation, morphology and expression of glial fibrillary acidic protein of an anaplastic astrocytoma cell line. Int J Cancer 42: 419-427.

Salim S, Ahmad M, Zafar KS, Ahmad AS, Islam F (2003) Protective effect of Nardostachys jatamansi in rat cerebral ischemia. Pharmacol Biochem Behav 74: 481-486.

Sauer H, Wartenberg M, Hescheler J (2001) Reactive oxygen species as intracellular messengers during cell growth and differentiation. Cell Physiol Biochem 11: 173-186.

Scapagnini G, Ravagna A, Bella R, Colombrita C, Pennisi G, Calvani M, Alkon D, Calabrese V (2002) Long-term ethanol administration enhances age-dependent modulation of redox state in brain and peripheral organs of rat: protection by acetyl carnitine. Int J Tissue React 24: 89-96.

Schipke CG, Ohlemeyer C, Matyash M, Nolte C, Kettenmann H, Kirchhoff F (2001) Astrocytes of the mouse neocortex express functional N-methyl-D-aspartate receptors. FASEB J 15: 1270 1272.

Sedlak J, Lindsay RH (1968) Estimation of total, protein-bound, and nonprotein sulfhydryl groups in tissue with Ellman's reagent. Anal Biochem 25: 192-205.

Sharma SK, Singh AP (2012) In vitro antioxidant and free radical scavenging activity of Nardostachys jatamansi DC. I Acupunct Meridian Stud 5: 112-118.

Simonian NA, Coyle JT (1996) Oxidative stress in neurodegenerative diseases. Annu Rev Pharmacol Toxicol 36: 83-106.

Singh J, Kaur G (2009) Transcriptional regulation of PSA-NCAM expression by NMDA receptor activation in RA-differentiated C6 glioma cultures. Brain Res Bull 79: 157-168.

Stewart VC, Stone R, Gegg ME, Sharpe MA, Hurst RD, Clark JB, Heales SJ (2002) Preservation of extracellular glutathione by an astrocyte derived factor with properties comparable to extracellular superoxide dismutase. J Neurochem 83: 984-991.

Subashini R, Ragavendran B, Gnanapragasam A, Yogeeta SK, Devaki $\mathrm{T}$ (2007) Biochemical study on the protective potential of Nardostachys jatamansi extract on lipid profile and lipid metabolizing enzymes in doxorubicin intoxicated rats. Pharmazie 62: 382-387.

Taurin S, Seyrantepe V, Orlov SN, Tremblay TL, Thibault P, Bennett MR, Hamet P, Pshezhetsky AV (2002) Proteome analysis and functional expression identify mortalin as an antiapoptotic gene induced by elevation of $[\mathrm{Na}+] \mathrm{i} /[\mathrm{K}+] \mathrm{i}$ ratio in cultured vascular smooth muscle cells. Circ Res 91: 915-922.

Terashvili M, Sarkar P, Nostrand MV, Falck JR, Harder DR (2012) The protective effect of astrocyte-derived 14,15-epoxyeicosatrienoic acid on hydrogen peroxide-induced cell injury in astrocyte-dopaminergic neuronal cell line co-culture. Neuroscience 223: 68-76. 
Toda M, Miura M, Asou H, Sugiyama I, Kawase T, Uyemura K (1999) Suppression of glial tumor growth by expression of glial fibrillary acidic protein. Neurochem Res 24: 339-343.

Vinutha B, Prashanth D, Salma K, Sreeja SL, Pratiti D, Padmaja R, Radhika S, Amit A, Venkateshwarlu K, Deepak M (2007) Screening of selected Indian medicinal plants for acetylcholinesterase inhibitory activity. J Ethnopharmacol 109: 359-363.

Wadhwa R, Kaul SC, Mitsui Y, Sugimoto Y (1993) Differential subcellular distribution of mortalin in mortal and immortal mouse and human fibroblasts. Exp Cell Res 207: 442-448.

Wang J, Wang X, Jiang S, Yuan S, Lin P, Zhang J, Lu Y, Wang Q, Xiong Z, Wu Y, Ren J, Yang H (2007) Growth inhibition and induction of apoptosis and differentiation of tanshinone IIA in human glioma cells. J Neurooncol 82: 11-21.
Yu HH, Hur JM, Seo SJ, Moon HD, Kim HJ, Park RK, You YO (2009) Protective effect of ursolic acid from Cornus officinalis on the hydrogen peroxide-induced damage of HEI-OC1 auditory cells. Am I Chin Med 37: 735-746.

Zhang R, Chae S, Kang KA, Piao MJ, Ko DO, Wang ZH, Park DB, Park JW, You HJ, Hyun JW (2008) Protective effect of butin against hydrogen peroxide-induced apoptosis by scavenging reactive oxygen species and activating antioxidant enzymes. Mol Cell Biochem 318: 33-42.

Zhang R, Kang KA, Piao MJ, Kim KC, Kim AD, Chae S, Park JS, Youn UJ, Hyun JW (2010) Cytoprotective effect of the fruits of Lycium chinense Miller against oxidative stress-induced hepatotoxicity. J Ethnopharmacol 130: 299-306. 